\title{
Enhancing the use of Decision Support Systems for Re-engineering of Operations and Business- Applied Study on the Palestinian Universities
}

\author{
Samy S. Abu Naser \\ Faculty of Engineering and Information Technology \\ Al Azhar University, \\ Gaza, Gaza-Strip, Palestine \\ abunaser@alazhar.edu.ps
}

\author{
Mazen J. Al Shobaki \\ Faculty of Engineering and Information Technology \\ Al Azhar University, \\ Gaza, Gaza-Strip, Palestine \\ mazen.alshobaki@gmail.com
}

\begin{abstract}
This research aims to promote the use of decision support systems and Re-engineering of Operations and Business - Applied Study of the Palestinian universities in Gaza. This study was applied on Palestinian University in Gaza strip, Palestine.
\end{abstract}

This research depends on decision support systems. Second dimension Re-engineering of Operations and Business was developed by the authors.

The control sample was (500). Several statistical tools were used for data analysis and hypotheses testing, including reliability correlation using Cronbach's alpha, "ANOVA", Simple Linear Regression and Step Wise Regression.

The overall findings of the current study suggest that no statistically significant impact on top management support to promote the use of decision support systems in the Re-engineering of Operations and Business at the universities in the Gaza Strip, the results highlighted that there is a statistically significant effect on the impact of decision support user systems type to promote the use of decision support systems in Reengineering of Operations and Business at Palestinian universities in the Gaza Strip, and that there are statistically significant differences between the mean study sample estimates of the impact of the decision support systems Reengineering of Operations and Business in Palestinian universities in Gaza due to the variable Gender in favor of males, and the existence of differences for the age variable relative to the field of "senior management support for the use of decision support systems" by the respondents, aged (45-55 years) and (55) years and over, and the presence of differences for the variable level of education relative to the field of "senior management support for the use of decision support" by the respondents, who hold master's degrees, and the existence of differences to the variable name of the university systems and that each area of study for the benefit of the Islamic University, Al-Azhar University and Al-Aqsa University, and the existence of differences for the variable years for service to the field of "senior management support for the use of decision support systems" by the respondents, who have service between (15-20) years and 21 years and over.

The current study is unique by the virtue of its nature, scope and way of implied investigation, as it is the first study at Palestinian Universities explores the status of Enhancing the use of Decision Support Systems for Re-engineering of Operations and Business, and Recommended increasing interest in decision support systems through continuity, keeping pace with technological means and modern techniques.

Keywords-Decision support systems; Senior management; Re-engineering; Universities; Higher Educational Institutions.

\section{INTRODUCTION}

The success and the development of educational organizations became subject to abiding by these organizations to the elements of modern management thought. Those ingredients that came as a logical consequence of what resulted from the trends of thought management through periods of its development as the effective management of educational organizations, is administration dealing with the integrated structure of the objectives and activities of human and material elements and the fact that there are several global variables imposed on educational organizations that manage to shift from reactive and slow to respond to the renewal of the management of the face of change and renewal site. This has resulted in these variables: the emergence of several directions contemporary and entrances in the management thought would contribute to the development of the management of educational organizations. The optimization and improvement in its performance, the most prominent of these trends, and contemporary entrances of what is known as the entrance and Re-engineering of Operations and Business.

The Palestinian universities are facing many difficulties and problems, most notably the weak capacity of employees in the Palestinian universities on the effective employment of information technology in the decision-making process [6]. 
Re-engineering confirms that the low work performance is mainly due to the traditional methods of work performance. The re-engineering runs from a general principle that means the educational systems and non-educational work or as a result of the way they are designed may succeed or fail [11]. Based on the above we can formulate the problem of study through the following main question: How to strengthen the use of Decision Support Systems for Re-engineering of Operations and Business- Applied Study on the Palestinian Universities in Gaza?

The objective of this study is to: highlight the importance of promoting the use of decision support systems in Re-engineering of Operations and Business at the Palestinian universities in Gaza Strip, identify to what extent infrastructure provides to decision support systems, indicate the role of decision support systems type used in promoting the use of decision support systems in the Re-engineering of Operations and Business at the Palestinian universities in Gaza Strip, stand on the role of top management support for decision support systems, identify the types of decision support systems used in the Palestinian universities in Gaza, and examine the role of demographic variables (university, Gender, age, educational qualification, years of service, job title) decision support systems and its impact on the Reengineering of operations and business in the Palestinian universities in Gaza.

The current study draws on the literature to explore this topic in depth and then turns to an implied investigation to assess and determine the most influential variables.

In view of the literature review, the study raises the questions:

Q1. Is promoting the use of decision support systems affect the Re-engineering of Operations and Business in the Palestinian universities in Gaza?

Q2. Is there an impact to promote the use of decision support systems and Re-engineering of Operations and Business in the Palestinian Universities in Gaza attributed to personal variables (gender, age, educational qualification, the university, and years of service)?

As for originality, the current study is unique by the virtue of its nature, scope and way of implied investigation, as it is the first study at the Universities in Palestine that explores enhancing the use of Decision Support Systems for Re-engineering of operations and business.

\section{LITERATURE REVIEW}

\section{A. Decision Support Systems:}

The main concept of decision support systems is to provide a system that allows direct interaction between the computer and the decision-maker without the mediation of information experts during the process of use. Decision support systems specializes in supporting decision makers by providing the data needed to solve problems of unstructured and semistructured models [7]. Where we can show a number of definitions of decision support systems. [24,27,28] defined DSS as one of the types of information systems based on computer where these systems facilitate the process of interaction between the human and information technology for the production of appropriate information to users' needs. [12] defined it as one of the types of systems that support decisionmaking activities within the administrative apparatus, where the decision-making process is the basis of the administrative process. Both of [17] defined it as an interactive information that provides managers with information, forms, and data processing tools that will help them in semi-structured and unstructured decision-making systems, in those circumstances that no one knows exactly what is the right decision to be taken. [9] defined it as a system capable of supporting the data analysis and special models in specific topics, and it is directed towards the strategic and long-term planning, and it can be used in irregular intervals.

DSS can achieve the goals mentioned by both Salmi, Al-Moghraby and Kelada which is to assist managers in making decisions to solve semi-structured problems (composite), and support the decisions of managers rather than changing it and improving the effectiveness of decision-making, and not just efficiency $[10,7,15]$.

Decision support systems consist of Inputs, Processes, Outputs, Feedback, and we'll explain each of these components as follows [13]:

Inputs: these inputs are natural resources such as information and data about the environment. In a University, the inputs can be students as materials. Classrooms, libraries, books and instructional media and laboratory as equipments. Faculty and administrative as individuals. Fees paid by students, government grants and investment returns as money. Knowing the market needs of skilled manpower and skills as information.

Processing: Any system that performs processing on the input coming from the environment to be converted into outputs. The university operations are as received by the students of lectures, seminars and exams in order to give them enough skills needed by society.

Outputs: After the data entry and processing of it, the system provide the surrounding environment with output. In the university, the students with their gained skills make up the university outputs.

Feedback: The system provides access to information about the previous three stages so that they can make desirable changes in any of them. In the university, for example, management may decide that you establish a new laboratory because the information indicates that the current number of laboratories is not enough. 
Featuring decision support systems the potential of high-analysis, where it is the design of these systems to include within it many of the data analysis models and based decision support systems on the use of programs characterized as easily as to encourage the direct use of the system, and is characterized by the use of such systems as interactive, that means it is based on the user's initiative by asking questions or changing assumptions analysis or enter new data to it [17].

Decision support systems are affected by a range of variables that make up those systems which affect and are affected by, and we will clarify them as follows:

Support of the senior management to decision support systems: the support of senior management should be clear to all through its willingness to take concrete action, including: drafting quality policy, building an organizational structure for quality, total involvement of employees, dissemination of information about the quality, change management processes, organize a quality day [25].

Types of decision support systems: there are seven types of decision support systems that are related to a range of general operations that can be performed by decision support systems and these types clarified [10]:

- File Drawer

- Data Analysis System

- Analysis Information System

- Accounting Models

- Representational Models

- Optimization Models Systems

- $\quad$ Suggestion Models

\section{B. Re-engineering of Operations and Business:}

The concept of re-engineering was introduced in 1990 by Michael Hammer in his published article in the Harvard Journal of Business Review and then spread rapidly in academia and in business and government. Hammer defined it as re-initial and basic thinking and redesigning administrative processes drastically in order to achieve improvements substantial super are not marginal (incremental) in the decisive performance criteria such as cost, quality, service and speed [14].

It was defined as the study and examination of the flow of the main operations and their own information for the purpose of re-designed, with the aim of simplification and cost reduction, quality improvement and achieve flexibility. But Al-Lawzi [5], defined it as sharp attention and caution in regulatory gap between the existing regulations with respect to performance and production levels by working on the development and modernization of working methods are helping to make a leap in performance over a short period of time. Khalil [16] defined it as the redesign of the organization of value-added operations through converting it from fragmented and distributed operations on different functions isolated from each other to combined with a vertical organizational structure to full operations distributed work teams, so that leads to all teams to do full operation, under organizational structure, with appropriate adjustments in each of the administrative systems and organizational culture, in order to maximize the value provided to the customer.

Al-Hashimi said that the information technology and communication play an important role in enabling the Re-engineering of Operations and Business achieve their goals, as this role has increased recently for the following reasons [3]:

The decline in the prices of information technology tools and cost of application.

The growing awareness of the need for personnel positive interaction with them in all areas of work.

Available financial possibilities that encouraged the use of information technology.

Organizations are not able to change their ideas and orientations toward information technology and invest as required will not be able to perform reengineering operations, where IT plays vital major role in the re-engineering of educational operations and this is evident from the possibility of use in the provision of communication with all units of the institution through an internal communications network that provides a basis for all units of data help to speed and accuracy of data acquisition, which helps to streamline and harmonize the performance and speed of decision-making and lack of inconsistency, as well as integration and interdependence between the one working parts within the institution to accomplish a coherent and harmonious systemic processes provide the necessary speed to make them acquire student satisfaction and guardian, and imagine new creative solutions to problems or hypothetical crisis yet to occur for training on how to manage when they occur and take the right decision at the right time.

Enhancing the use of Decision Support Systems for Re-engineering of operations and business in the Palestinian Universities leads to the following main hypothesis in this study:

H1: There is no statistically significant effect at the level of significance $(\alpha \leq 0.04)$ between the promotion of the use of decision support and Re-engineering of operations and business systems in the Palestinian universities in Gaza.

This leads to the following first sub-hypothesis in this study:

h1-1: There are no statistically significant at the level of significance $(\alpha \leq 0.04)$ to senior management support in promoting the use of decision support systems and Re-engineering of operations and business in the Palestinian universities in Gaza. 
h1-2: There is no statistically significant effect at the level of significance $(\alpha \leq 0.04)$ for the type of decision support systems used in promoting the use of decision support systems and Re-engineering of Operations and Business in the Palestinian universities in Gaza.

H2: There are no statistically significant effect among respondents responses at the level of significance ( $\alpha \leq$ 0.04 ) on the promotion of the use of decision support systems in Re-engineering of Operations and Business - A Case Study on the Palestinian Universities in Gaza attributed to personal variables (gender, age, qualification scientific, university, years of service).

\section{RESEARCH DESIGN}

\section{A. Study population and sampling:}

This study conducted at the following Palestinian Universities in Gaza Strip - Palestine: Islamic University, Al-Azhar University, and Al-Aqsa University. The population are (456) employees, the control sample was (500). The usable sample was (449), which makes the response rate (89.8\%). And the research sample is a stratified random sample according the results as shown in Table (1).

TABLE I.

THE STUDY SAMPLE

\begin{tabular}{|c|c|}
\hline The University & Total Summation \\
\hline Al-Azhar University & 266 \\
\hline Islamic University & 524 \\
\hline Al-Aqsa University & 332 \\
\hline Total & 1122 \\
\hline
\end{tabular}

Source: Universities Personnel Department in question 2016.

Table (1) shows that a rate (83.3\%) of the study sample is male. This is consistent with all studies that have been in the Arab Environment, which showed that male workers is higher than the proportion of females. A rate (89.1\%) aged greater than (25) years, and $(81.5 \%)$ of the sample hold at least bachelor degree. The researchers attributed that to the dedication of the Palestinian universities in Gaza in choosing scientifically qualified staff and able to keep up with development, technological development and management. A rate (26.3\%) of the sample from $\mathrm{Al}$ Azhar University, (45.5\%) from the Islamic University, $(28.1 \%)$ of the Al-Aqsa University. The researchers attribute that to the fact that the number of administrators and the number of academic administrative job at Al-Azhar University (266) and at the Islamic University (524), and in the administrative in Al-Aqsa University (332). (48.5\%) of the study sample have less than 10 years of service, and researchers attribute that to the fact that Palestinian universities are relatively new in Gaza.
TABLE II.

THE STATISTICAL DESCRIPTION OF THE SAMPLE ACCORDING TO THE CHARACTERISTICS AND PERSONALITY TRAITS $(\mathrm{N}=415)$

\begin{tabular}{|c|c|c|c|}
\hline \multicolumn{2}{|r|}{$\begin{array}{l}\text { Characteristics and } \\
\text { personality traits }\end{array}$} & \multirow{2}{*}{ 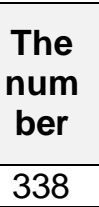 } & \multirow{2}{*}{$\begin{array}{c}\text { Perce } \\
\text { ntage } \\
\%\end{array}$} \\
\hline Gend & Male & & \\
\hline er & Female & 68 & $16.7 \%$ \\
\hline \multirow{5}{*}{ Age } & Less than 25 years & 49 & $10.9 \%$ \\
\hline & $\begin{array}{l}\text { From } 25 \text { years to less } \\
\text { than } 35 \text { years }\end{array}$ & 155 & $34.6 \%$ \\
\hline & $\begin{array}{l}\text { From } 35 \text { years to less } \\
\text { than } 45 \text { years }\end{array}$ & 126 & $28.1 \%$ \\
\hline & $\begin{array}{l}\text { From } 45 \text { years to less } \\
\text { than } 55 \text { years }\end{array}$ & 86 & $19.2 \%$ \\
\hline & From 55 years and over & 32 & $7.1 \%$ \\
\hline \multirow{5}{*}{$\begin{array}{c}\text { Qualif } \\
\text { icatio } \\
\text { n }\end{array}$} & High school or less & 17 & $3.8 \%$ \\
\hline & Intermediate Diploma & 66 & $14.7 \%$ \\
\hline & BA & 236 & $52.6 \%$ \\
\hline & M.A. & 61 & $13.6 \%$ \\
\hline & PhD. & 69 & $15.4 \%$ \\
\hline \multirow{3}{*}{$\begin{array}{l}\text { Unive } \\
\text { rsity } \\
\text { Name }\end{array}$} & Al-Azhar University & 118 & $26.3 \%$ \\
\hline & Islamic University & 204 & $45.5 \%$ \\
\hline & Al-Aqsa University & 126 & $28.1 \%$ \\
\hline \multirow{5}{*}{$\begin{array}{c}\text { Years } \\
\text { of } \\
\text { servi } \\
\text { ce }\end{array}$} & Less than 5 years & 98 & $21.9 \%$ \\
\hline & $\begin{array}{l}\text { From } 5 \text { years to less } \\
\text { than } 10 \text { years }\end{array}$ & 119 & $26.6 \%$ \\
\hline & $\begin{array}{l}\text { From } 10 \text { years to less } \\
\text { than } 15 \text { years }\end{array}$ & 123 & $27.5 \%$ \\
\hline & $\begin{array}{l}\text { From } 15 \text { years to } 20 \\
\text { years }\end{array}$ & 57 & $12.7 \%$ \\
\hline & From 21 years and over & 51 & $11.4 \%$ \\
\hline
\end{tabular}

\section{B. Research instrument:}

The first dimension referring to Decision Support Systems, The second dimension of the instrument which measure Re-engineering of Operations and Business. These statements were further revised and modified by experts in a subsequent stage before drafting the final version of the questionnaire.

A five-point Lekert scale of agreement was used for measurement, running from "Strongly Agree" to "Strongly Disagree", with a Neutral category for scale midpoint.

\section{Validity and reliability assessment:}

The study adopted Cranach's a to measure the internal consistence reliability of the questionnaire. The results showed that Cronbach's a values for all dimensions were $>(0.4)$. It indicated that the design of the questionnaire had a high internal consistency.

\section{Statistical procedures:}

Several statistical tools were used for data analysis and hypotheses testing, including reliability Correlation using Cronbach's alpha, "ANOVA", Simple Linear Regression, OLS- Ordinary Least Squares and Step Wise Regression. 


\section{E. Data analysis and discussion of results:}

Simple linear regression and "ANOVA" tests were used to test hypotheses. Simple linear regression used to test whether there is an impact for one independent variable on a single dependent variable (Reengineering of operations and business).

The results of regression test indicate that sig. is less than (0.04) for all independent variables, which mean that there are significant statistically effect for independent variables on Re-engineering of operations and business.

Pearson coefficient and regression coefficient Signe for all independent variables was positive. This result means whenever the value of independent variables increase, there will be increase in performance.

Changes in the independent variable is responsible for the interpretation of a rate ( $r 2$ ) of all the changes that occur in performance, and there is a rate (100 - r2) due to other factors specific to the other independent variables and other factors not mentioned in the decision support system, in addition to the random error.

The table reveals that the findings of Significance level are less than (0.04), which means that we can rely on the previous model and circulating the sample results on research community.

Therefore, the results of the analysis proved the existence of a relationship between the independent variable and the dependent variable, and each dimension in the independent variable effect individually on the dependent variable. Therefore, we accept the main hypothesis and it is sub-hypotheses.

\section{a) Testing the research hypotheses:}

h1: There is no statistically significant effect at the level of significance $(\alpha \leq 0.04)$ between the promotion of the use of decision support systems and Reengineering of Operations and Business in the Palestinian universities in Gaza.

This leads to the following first sub-hypothesis in this study:

h1-1: There are no statistically significant effect at the level of significance $(\alpha \leq 0.04)$ to senior management support in promoting the use of decision support systems and Re-engineering of Operations and Business in the Palestinian universities in Gaza.

TABLE III. THE CORRELATION COEFFICIENT BETWEEN THE SENIOR MANAGEMENT SUPPORT OF DECISION SUPPORT SYSTEMS AND RE-ENGINEERING OF OPERATIONS AND BUSINESS

\begin{tabular}{|c|c|c||}
\hline The field & $\begin{array}{c}\text { Pearson } \\
\text { correlation } \\
\text { coefficient }\end{array}$ & Sig. \\
\hline $\begin{array}{c}\text { Senior management } \\
\text { Support of decision } \\
\text { support systems }\end{array}$ & .686 & $* 0.000$ \\
\hline
\end{tabular}

*Link statistically significant at the level $\alpha=0.04$.
Table (3) shows that the correlation coefficient between the senior management Support of decision support systems and re-engineering of operations and business is equal to $(0.686)$, and that the probability value (Sig.) is equal to $(0.000)$ which is less than the significance level $(\alpha \leq 0.04)$. So we can say that there is statistically significant effect at $(\alpha \leq 0.04)$ between the senior management support of decision support systems and re-engineering of operations and business at Palestinian universities in Gaza. The researchers attribute the fact that senior management support of decision systems is important for the reengineering of operations and business and this agrees with the study [1] which showed that the senior management must recognize the importance of the use of decision support systems.

h1-2: There is no statistically significant effect at the level of significance ( $\alpha \leq 0.04$ ) for the type of decision support systems used in promoting the use of decision support systems and Re-engineering of operations and business in the Palestinian universities in Gaza.

TABLE IV THE CORRELATION COEFFICIENT BETWEEN THE TYPE OF DECISION SUPPORT SYSTEMS USED AND REENGINEERING OF OPERATIONS AND BUSINESS

\begin{tabular}{|c|c|c||}
\hline The field & $\begin{array}{c}\text { Pearson } \\
\text { correlation } \\
\text { coefficient }\end{array}$ & Sig. \\
\hline $\begin{array}{c}\text { The type of } \\
\text { decision support } \\
\text { systems used }\end{array}$ & .643 & ${ }^{*} 0.000$ \\
\hline
\end{tabular}

Table (4) shows that the correlation coefficient between The type of decision support systems used and re-engineering business processes and systems is equal to the type (0.643), and that the probability value (Sig.) is equal to (0.000) which is less than the significance level $(\alpha \leq 0.04)$. It could be argued that there is a statistically significant relationship at the level of $(\alpha \leq 0.04)$ between the type of decision support systems used and re-engineering of operations and business at the Palestinian universities in Gaza, the researchers attributes that it is essential that modern programs accomplish recurring operations and have the ability to retrieve information quickly and submit periodic reports, in order to carry out the process of rereengineering of operations and business, and this is consistent with a study [4], which showed the need to provide all kits for applying decision support system because of its importance in the decision taken by the managers in the field of continuous improvement for the work in the organization.

\section{b) All fields together}

h1: There is no statistically significant effect at the level of significance $(\alpha \leq 0.04)$ between the promotion of the use of decision support and Re-engineering of 
Operations and Business in the Palestinian universities in Gaza systems.

TABLE V.

THE CORRELATION COEFFICIENT BETWEEN THE DECISION SUPPORT SYSTEMS AND RE-ENGINEERING OF OPERATIONS AND BUSINESS

\begin{tabular}{|c|c|c|}
\hline The field & $\begin{array}{c}\text { Pearson } \\
\text { correlation } \\
\text { coefficient }\end{array}$ & Sig. \\
\hline $\begin{array}{c}\text { Decision Support } \\
\text { Systems }\end{array}$ & .811 & ${ }^{*} 0.000$ \\
\hline
\end{tabular}

* SMA statistically significant at the level of significance $0.04=\alpha$.

Table (5) shows that the general correlation coefficient between decision-support systems and reengineering of operations and business in Palestinian universities in Gaza is equal to (0.811). The probability value (Sig.) is equal to $(0.000)$ which is less than the significance level $(\alpha \leq 0.04)$. So we can say that there is statistically significant effect at $(\alpha \leq 0.04)$ between the decision support systems and re-engineering of operations and business in Palestinian universities in Gaza, where the decision support systems is one of the main determinants of the success of the application of re-engineering of operations and business in Palestinian universities in Gaza. This is consistent with study [4] which showed that it is necessary to provide all kits for applying decision support system because of its importance in the decision taken by the managers in the field of continuous improvement for the work in the organization.

H2: There was no statistically significant effect among respondents responses at the level of significance $(\alpha \leq 0.04)$ on the promotion of the use of decision support systems in Re-engineering of Operations and Business - A Case Study on the Palestinian Universities in Gaza are attributable to personal variables (gender, age, qualification scientific, university, years of service).

$T$ test was used in the case of two independent samples to see if there was a statistically significant differences. This test fit to compare the average of two sets of data. "Analysis of variance" test was used to see if there exists a statistically significant differences. This test is fit to compare (3) or more averages.

From the results shown in the table (6), the probability value (Sig.) is greater than the significance level 0.04 of the variables "age, education level, years of service," and thus it can be concluded that there is no significant differences between the averages of the answers of respondents differences on promoting the use of decision support systems in process of reengineering of operations and business - Case study on the Palestinian universities in Gaza due to the variables "age, education level, years of service".

These results agreed with some studies as the study of Al- Nakhala [8], which concluded that no statistically significant differences due to (qualification) for the benefit of those who have graduate studies.
As for the variables "gender" and "the university", it has been shown that the probability value (Sig.) is less than the significance level of (0.04) and thus it can be concluded that there are significant differences between the averages of the answers respondents on promoting the use of decision support systems in the re-engineering of operations and business - Case Study on Palestinian universities in Gaza due to the variables "gender", "the university". These results agreed with the study [1], which showed that there were statistically significant differences on the reality of the decision support systems in the Palestinian universities in Gaza, due to the variable gender in favor of males. These results did not agree with the study [8], which indicated that there were no statistically significant differences between the averages of the study sample estimates are attributable to variable gender.

TABLE VI. "T - TEST RESULTS OF TWO INDEPENDENT SAMPLES AND VARIANCE" - PERSONAL VARIABLES

\begin{tabular}{|c|c|c|c|}
\hline Variable & Test name & $\begin{array}{c}\text { The } \\
\text { value of } \\
\text { the test }\end{array}$ & Sig. \\
\hline Gender & $\begin{array}{c}\text { For two } \\
\text { independent } \\
\text { samples T }\end{array}$ & 3.551 & ${ }^{*} 0.000$ \\
\hline Age & Variance & 1.503 & 0.100 \\
\hline $\begin{array}{c}\text { Educational } \\
\text { level }\end{array}$ & Variance & 1.196 & 0.155 \\
\hline University & Variance & 80.458 & ${ }^{*} 0.000$ \\
\hline $\begin{array}{c}\text { Years of } \\
\text { service }\end{array}$ & Variance & 0.610 & 0.328 \\
\hline
\end{tabular}

* The difference between the averages are statistically significant at the 0.04 level of significance

\section{CONCLUSION:}

The results showed no statistically significant impact at the level of significance $(\alpha \leq 0.04)$ on senior management support to promote the use of decision support systems in the Re-engineering of operations and business at universities in the Gaza Strip. The senior management supports the existence of decision support systems, care for the decision support systems as part of a comprehensive regulatory development process, relies on decision support systems in their decisions, encourages employees to use decision support systems, as well as they care for diagnosis of problems that hinder the performance of decision support systems to some extent, they are working to overcome the obstacles that hinder the development of decision support systems to some extent, the senior management provide the necessary staff to carry out the process of decision support systems to some extent.

Results highlighted that there is a statistically significant effect at the level of significance $(\alpha \leq 0.04)$ on the impact of decision support systems of the type used to promote the use of decision support systems in the re- engineering and business operations at Palestinian universities in the Gaza Strip, as the 
software used in universities have the ability to retrieve information quickly, and programs used in these universities are recent, where they are able to prepare special reports, and working to accomplish repetitive operations, and submit periodic reports covering aspects of the work.

The results showed, for the field of Re-engineering of operations and business on Palestinian universities in the Gaza Strip, an increase of the use of information technology that are able to coordinate operations at faculties and various departments and divisions. Staff working in these universities mange information from any location through the use of computers. Universities use Internet in the internal and external communications among employees. The information and data in the universities are characterized by its abundance and easily dealt with leading to the performance of the business quickly and accurately. The laws and regulations clarify tasks and functions. The use of information technology in universities has led to the ability to redesign its administrative operations. Leadership of the university is aware of the concept of Re-engineering of operations and business architecture which ensures the progress and development. They keep pace with technological developments in the area around the university environment. The strategic plan for universities is clear, well written, and that it is working on an analysis of strengths and weaknesses, opportunities and threats points facing universities, as well as university leadership exercised principle of subsidiarity in decision-making. Administrative policies in the universities are clear and understandable and work somewhat to guide the process of making and decision-making towards the development of performance and also to some extent generate confidence among staff and alleviate cases of doubt and confusion. The organizational structure of universities help to speed administrative contact, as well as helping to achieve the goals; furthermore, there is a fairly constant plan for the development of workers in the universities.

There are statistically significant differences at the level of significance ( $\alpha \leq 0.04$ ) between the mean study sample estimates about the effect of decision support systems to Re-engineering of Operations and Business on the Palestinian universities in Gaza due to the variable Gender in favor of males. The existence of differences for the age variable relative to the field of " Senior management support for the use of decision support systems" by the respondents, aged (45-55) years and 55 years and over.

The existence of differences for the variable level of education relative to the field of "Senior management support for the use of decision support systems" by the respondents, who hold a master's degree.

The existence of differences to the variable name of the university and that each area of study for the benefit of the Islamic University, Al-Azhar University, and Al-Aqsa University. The existence of differences for the variable years of service in relation to the field of "Senior management support for the use of decision support systems" by the respondents, who have years of service of between (15-20 ) years and 21 years and over.

Clarify the importance of re-engineering of operations and business of the Palestinian universities in Gaza, which do not have a tendency for Reengineering of operations and business, and encourage Palestinian universities in Gaza, which are planning to Re-engineering of operations and business to start implementing the programs in a radical change as soon as possible. The need for the Palestinian universities in Gaza to develop the infrastructure for information technology in general, and decision support systems in particular, when doing reengineering operations. The need for a separate unit of decision support systems and organizational structure to allow information to flow seamlessly between faculties and various departments and divisions. Increased interest in decision support through continuity keeping pace with technological tools and techniques of modern systems.

\section{REFERENCES}

[1] Abu-Taim, Mohammad Omar Suleiman (2015), "Decision-support and their relationship to effective management decision - field research on the administrative staff at universities Palestinian-Gaza governorates systems", Unpublished Master Thesis, Al-Azhar University in Gaza, Faculty of Economics and administrative Sciences, Gaza, Palestine.

[2] Ahmed, Shaker (2005): total quality management and excellence University, Fifth Educational Conference, the quality of university education, Bahrain April 11 to 13, 2005, Volume I, Kingdom of Bahrain.

[3] Al-Hashimi, Shaima Mohammed Saleh, (2003): The Role of IT in Business Process Reengineering: The Case of the Faculty of Management and Economics, Master Thesis study (unpublished), College of Management and Economics, University of Mosul, Iraq

[4] Al-Hayali, Ahmed Moayed, Attia, El Jarjari, Ahmed Hussein Hassan (2012): "The extent of contributions to decision support in the implementation of the continuous improvement of Nizat- survey of the views of a sample of employees of ready-made clothes factory in the city of Mosul system," College of Management and Economics, University of Mosel, Two Rivers development, No. 110, Vol. 34, p: (217-236), Iraq.

[5] Al-Lawzi, Moses (1999): OD the fundamentals and concepts of modern, the first edition, Dar Wael for printing and publishing, University of Jordan, Amman, Jordan.

[6] AL-Masry, Marwan (2007): administrative performance of the heads of academic departments to develop the Palestinian universities in the light of the 
principles of Total Quality Management, Master Thesis (unpublished), the Islamic University, Gaza, Palestine.

[7] AL-Moghraby, Abdul Hamid (2002): Management Information Systems foundations and principles, Mansoura University, Mansoura, Egypt.

[8] AL-Nakhalah, Najla Jamal (2015), "depicting a proposal for the development of department heads performance in the departments of Education and the provinces of Gaza in light of the Business Process Reengineering method (Reengineering)," Master Thesis (unpublished), the Islamic University, Gaza, Palestine.

[9] Al-Omari, Ghassan al-Samarrai, Salwa (2008): Strategic Information Systems - strategic entrance to the contemporary, Faculty of Administrative and Financial Sciences, the first edition, Isra University, Dar maserah, Jordan.

[10] Al-Salmi, Alaa Abdul Razzaq (2003): Information Management Systems, the Arab Organization for Administrative Development, Cairo publications, Egypt.

[11] Al-thbyti, Juwaibiri, and Aqil, Hamza (2002): Model re-work in academic departments Engineering (Case Study), educational and social studies, Faculty of Education, Helwan University, Volume VIII, Issue III, Egypt.

[12] Champi, James (2003): Re-Engineering Management (inevitable requirement for the new leadership), Riyadh, Saudi Arabia.

[13] Haider, HE Fahmi (2002): Information Systems entrance to achieve competitive advantage, University House, Alexandria, Egypt.

[14] Hassania, Salim (1998): Management Information Systems, the first edition and the second, Warraq Foundation, Amman, Jordan.

[15] Hummer, Michael Chambi, James (1996): Reengineering of Operations and Business organizations, the Arab Company for scientific statement (beam), Cairo, Egypt.

[16] Kelada, Joseph (2004): Integration with the re-engineering of Total Quality Management, Dar Mars, Riyadh.

[17] Khalil, Atallah Warad (2008): The role of engineering operations in decisions support to reduce costs in light of the philosophy of change management, working paper submitted to the Eighth Annual International Scientific Conference, Change Management and Knowledge Society, April 24 to 21 (April), Faculty Economics and administrative Sciences, Zaytuna University of Jordan, Amman, Jordan.

[18] Kurdish, Manal Mohammed, and Al-abed, Jalal Ibrahim (2003): Introduction to Management Information Systems) the basic concepts and applications (new University House, Alexandria, Egypt.

[19] Lowenthal, Jeffrey (2002): the organization reengineering -step-by-step approach, Dar Al Marekh, Riyadh, Saudi Arabia.

[20] Mashreky, Hassan Ali (1997): administrative decisions Theory -Quantitative Approach in management, the first edition, Dar march Amman, Jordan

[21] Obaid, Abdul Salam Ibrahim, and kareem, Fadel Abbas (2014): "Re- engineering university performance according academic requirements analytical study in technical institutes requirements," a paper presented to a scientific conference of the University of Kufa, the fifth annual conference of the Quality Assurance and Accreditation, under the slogan of our way of continuous improvement to ensure the quality of higher education, Iraq.

[22] Saeed, Abdul Ghani Mohammed Abdo (2013): "the development of research universities performance management in Yemen re-engineering perspective: Visualize proposal", PhD thesis (unpublished), Cairo University, Institute of Educational Studies, Department of Foundations of Education, Egypt.

[23] Sheraz, Haeyf C, Haevf (2015): "process reengineering as a strategic choice and competitive organization to improve the situation Telecom Algeria, Mobilis company study", No. XVIII, Journal of economic and administrative Research, December 2015, Vol. 18, Algeria

[24] Sobaih, Lena (2013): "A future vision for Palestinian university re- engineering education systems in the light of the requirements of a knowledge society", Unpublished PhD thesis, Ain Shams University, Egypt.

[25] Sultan, Ibrahim (2007): Management information systems, administrative entrance, University House, Alexandria, Egypt.

[26] Zaher, Ziauddin (2005): Educational Systems of Total Quality Management, Dar Al-Sahab, Cairo, Egypt.

[27] Abu Naser S. S., A Al-Masri, Y Abu Sultan, I Zaqout,(2011), A prototype decision support system for optimizing the effectiveness of elearning in educational institutions, International Journal of Data Mining \& Knowledge Management Process, 1(4).

[28] Abu Naser S. S., Al Shobaki M .J., (2016), Requirements of using Decision Support Systems as an Entry Point for Operations of Re-engineering in the Universities (Applied study on the Palestinian universities in Gaza Strip), World WideJournal of Multidisciplinary Research and Development, 2(4). 